IFN Working Paper No. 877, 2011

\title{
Political Preferences and Public Sector Outsourcing
}

Mikael Elinder and Henrik Jordahl 


\title{
Political preferences and public sector outsourcing*
}

June 30, 2011

\author{
Mikael Elinder ${ }^{\mathrm{a}}$, \\ ${ }^{a}$ Uppsala University and the Research Institute of Industrial Economics (IFN); Department of Economics, Uppsala \\ University, P.O. Box 513, S-75120 Uppsala, Sweden.Email: mikael.elinder@nek.uu.se.
}

\author{
Henrik Jordahl ${ }^{\mathrm{b}}$ \\ ${ }^{\mathrm{b}}$ The Research Institute of Industrial Economics (IFN), P.O. Box 55665, SE-102 15 Stockholm, Sweden. E-mail: \\ henrik.jordahl@ifn.se
}

\begin{abstract}
A B S T R A C T
There are several theoretical accounts of public sector outsourcing. We note that leading theories give different predictions of the influence of political variables and test the predictions on a Swedish data set in which outsourcing varies between municipalities and over time as well as between services. Our identification strategy focuses on two services with similar contracting problems and local market conditions: preschools and primary schools. We study a period in which Swedish municipalities had full discretion in the provision of preschools, while their influence on the provision of primary education was limited by a national voucher system. The comparison of preschools and primary schools in a difference-in-differences model suggests that the political color of the ruling majority matters for outsourcing, which is consistent with the citizen candidate model of representative democracy.
\end{abstract}

JEL classification: D23, H11, H40, L33

Keywords: outsourcing, ideology, public provision, contracting out

\footnotetext{
* We wish to thank Niklas Kaunitz, Che-Yuan Liang, Erik Lindqvist, and Daniel Waldenström, as well as seminar participants at the Uppsala Center for Fiscal Studies, for helpful comments and suggestions. Niklas Kaunitz and Thomas Wilhelmsson provided excellent research assistance. Financial support from the Swedish Competition Authority (Elinder) and the Jan Wallander and Tom Hedelius Foundation (Jordahl) is gratefully acknowledged.
} 


\section{Introduction}

The last 30 years have witnessed an intensive, ideologically charged debate over the use of private contractors for publicly funded services such as education and health care. With this in mind, it is notable that many social scientists have preferred to use the pursuit of economic efficiency to explain government outsourcing. Building on Coase (1937), Williamson $(1981,1985)$ and Grossman and Hart (1986), the Transaction cost model of Hart, Shleifer and Vishny (1997) explains outsourcing by the contracting difficulties of different services.

Other models of government outsourcing or of policymaking in general have more of a political flavor and assume that politicians are motivated by holding office or by influencing policy. The Patronage model of government outsourcing (Lopez-de-Silanes, Shleifer and Vishny, 1997) and the Downsian model of electoral competition (Downs 1957) have office motivated politicians. Politicians who are motivated by policy are to be found in the Citizen candidate model of Osborne and Slivinsky (1996) and Besley and Coate (1997).

According to the Patronage model, politicians derive significant benefits from in-house provision, including support from public employee unions and the ability to control unemployment through public payrolls. The cost of patronage is that it has to be paid for by higher taxes, which is something voters generally dislike. The Patronage model predicts that politicians will choose lower levels of outsourcing than voters prefer, but that this difference will be smaller in competitive elections. As is well known, the Downsian model predicts policy convergence even if the competing politicians prefer different policies. The policy outcome is determined by the preferences of the median voter. In the Citizen candidate model, politicians are motivated to run for office by the prospect of implementing their own preferred policy. Unlike the Downsian model, policies are expected to diverge such that outsourcing - like other political choices - depends on the identity of the winning side in elections.

Previous empirical studies have arrived at varying conclusions. Based on a literature review and some meta-regressions, Bel and Fageda $(2007,2009)$ conclude that a general explanation of local government outsourcing has been hard to find. In any case, local outsourcing seems to be guided by pragmatic cost considerations rather than ideological motivations. If anywhere, ideology seems to matter in Europe and in large cities. Studies that report that political preferences are unrelated to outsourcing include McGuire, Ohsfeldt and van Cott (1987), Dijkgraaf, Gradus and Melenberg (2003), and Zullo (2009). Bhatti, Olsen, and Pedersen (2009) on the other hand report that Danish municipalities with a conservative or liberal majority utilize contracting more than municipalities with majorities to the left in politics. Lopez-de-Silanes, Shleifer, and Vishny (1997) find that the Patronage model explains outsourcing in U.S. counties. Brown and Potosky (2003) and Levin and Tadelis (2010) instead present evidence from local governments in the United States that supports the Transaction cost model of public sector outsourcing. When it comes to Sweden, Ohlsson (2003) finds that cost 
differences did not affect outsourcing decisions of refuse collection in the municipalities, suggesting that policy makers did not minimize costs.

Unlike the previous empirical studies of public sector outsourcing we test different theories in a coordinated fashion. Instead of a large battery of explanatory variables from different theories, we focus on two political variables that give different predictions, according to four influential theories. The Transaction cost, the Patronage, and the Downsian model do not predict the color of the ruling majority to have any effect on outsourcing. The Citizen candidate model on the other hand predicts that right majorities will opt for higher levels of outsourcing than left majorities. The four theoretical models also differ in their predictions when it comes to the effect of the preferences of the electorate, which we measure by vote shares for the right bloc of parties.

We make use of data on outsourcing in Swedish municipalities. For several reasons, Swedish municipalities provide a suitable testing ground for the models that we have described. First, we have data in which government outsourcing varies between publicly financed services and between municipalities, as well as over time. The data contain information on the outsourcing shares of several services in 290 municipalities from 1998 to 2006. This is a considerable improvement compared with previous studies, which have either lacked the time dimension or have been limited to a single service (e.g., garbage collection). ${ }^{1}$

Second, Sweden has witnessed an ideological realignment in which the number of municipalities governed by right parties has increased considerably since around 1990. It is quite suggestive that this trend coincides with a steady increase in local government outsourcing. The Transaction costs model predicts that outsourcing will differ between services rather than between municipalities (for the same service) or over time. Thus, the Transaction costs model can neither account for the observed general increase in outsourcing nor for the fact that outsourcing varies widely between municipalities. ${ }^{2}$

Third, we are able to test the models with a difference-in differences strategy, making use both of similarities and differences between preschools and primary schools. Preschools and primary schools are similar services when it comes to contracting difficulties and local market conditions. However, the legislative treatment of these two services has differed considerably. The provision of preschools was fully determined by municipal discretion between 1992 and 2006. During the same period, a voucher system effectively limited the influence of local politicians on the mix between

\footnotetext{
${ }^{1}$ Using cost shares of outsourcing is also an improvement compared with most of the studies in the literature which are conducted within a discrete choice framework. For example Brown and Potoski (2003) and Levin and Tadelis (2010) both use dummy dependent variables for mode of production (partly or fully contracted out).

${ }^{2}$ Since the savings from outsourcing seems to be quite large when the public sector is first opened up for competition (Andersson and Jordahl 2011), the fact that a lot of municipalities produce several services fully inhouse is another shortcoming of the transaction costs model.
} 
public and private primary schools. The municipality has to finance private schools that meet national requirements and attract pupils. We test how the political color of the local majority and the outsourcing preferences of the electorate influence differences in outsourcing between preschools and primary education.

We find that political preferences matter for the choice between outsourcing and in-house production in Swedish municipalities. This finding appears both as a general visual pattern in our data and in econometric tests where we address selection problems by making use of the similar service characteristics and different legal regulations of preschools and primary schools. The presented evidence is consistent with the Citizen candidate model. Other economic and political models (the Transaction cost, the Patronage, and the Downsian model) are inconsistent both with the general development of outsourcing in the Swedish public sector and with our econometric estimates.

The paper proceeds by a description of the context of the empirical analysis, followed by section 3 , in which we provide a picture of the trends and patterns in the data. Section 4 describes how we deal with some empirical problems, including selection issues, and section 5 clarifies the theoretical predictions in terms of estimated parameters. Section 6 presents the results of the formal tests of the models. Finally, section 7 concludes.

\section{Local politics and publicly provided services in Sweden}

Sweden is a welfare state characterized by high taxes, generous benefits, and a large public sector. The public sector is organized into three levels: municipalities, counties and the national level. The 290 municipalities are entrusted with a constitutional right of self-governance, including levying income taxes and deciding on local public spending. The municipalities are required by legislation to provide child care and early childhood education, primary and secondary education, elderly care, and some other services. Health care is mainly provided at the county level. In 2006, total municipal expenditure made up 29 percent of total public sector expenditure and 15 percent of GDP. ${ }^{3}$ A large share of the total costs of the municipalities (69 percent) is made up by the three services elderly care (30 percent), primary and secondary education (26 percent), and preschools (13 percent).

For our purposes, it is important that municipalities are in general free to decide whether they should produce a service in-house by municipal employees or to provide the service through outside contractors. For primary education, however, there is a voucher system with free entry for private providers that meet national requirements. The municipality has to finance private providers that meets these requirements and attracts pupils. For preschools, the municipalities were free to decide between in-house production and contracting out between 1992 and 2006. Since then, the system is similar to that for primary education with free entry for private providers. Since we make use of this institutional

\footnotetext{
${ }^{3}$ Statistics Sweden, Public Finances in Sweden 2008.
} 
difference between preschools and primary education, we briefly describe the rules and regulations governing these two municipal services below.

\section{Primary education}

Before 1992, pupils had to attend the public school in their local area. In 1992, a reform was implemented that allowed parents and pupils to choose a private school and required the municipalities to pay private schools for each pupil at a rate corresponding to 85 percent of the average expenditure in the public schools in the same municipality. The guiding principle behind the reform is that public and private schools should compete on equal terms. All schools have to follow the national curriculum. The private schools are not allowed to charge fees (including top-up fees) or to select pupils by ability, socio-economic characteristics or ethnicity. ${ }^{4}$ The proportion of pupils in private schools has grown steadily since 1992. In 2006, 8 percent of all pupils in primary education (and 15 percent of all pupils in secondary education) were enrolled in private schools. ${ }^{5}$ The urbanized areas of south and middle Sweden (the Greater Stockholm area in particular) have the highest concentration of pupils in private schools.

\section{Preschools}

The municipalities are also legally required to provide preschools and school-age child care for children between the age of 1 and 12, allowing parents to work or study. In 2006, 79 percent of children between the age of 1 and 5 were enrolled in municipally financed preschools: 83 percent in municipal and 17 percent in private units. There were private preschools in 80 percent of the municipalities. ${ }^{6}$ The most popular private preschools are for-profit companies and parents' cooperatives (with 37 and 32 percent of the children in non-municipal preschools respectively). ${ }^{7}$

Preschools are heavily subsidized by the municipalities and the subsidies have, since the 1980s, been made more accessible to private providers. This stepwise process started in 1984 when parents' cooperatives and day-care centers with special forms of pedagogy were allowed to receive municipal subsidies. Subsidies to for-profit companies were introduced in 1992. Until 2006, the municipalities made discretionary decisions in each individual case, but since 2006, they have to grant subsidies to non-municipal preschools and leisure time centers that meet national standards.

\footnotetext{
${ }^{4}$ See Böhlmark and Lindahl (2008) for a description of the 1992 reform.

${ }^{5}$ Statistics Sweden, Utbildningsstatistisk årsbok 2008 [Yearbook of Educational Statistics 2008], p. 76.

${ }^{6}$ Swedish National Agency for Education, http://www.skolverket.se/content/1/c4/92/23/BO_Barn\%20och\%20grupper_Riksniv\%E5_Tabell1A.xls (accessed June 17, 2011).

${ }^{7}$ Swedish National Agency for Education, http://www.skolverket.se/content/1/c4/92/23/F\%F6rskola_Barn\%20och\%20grupper_Riksniv\%E5_Tabell4.xls
} 


\section{Local politics in Sweden}

Politically, Sweden is often treated as a fairly stable two-bloc system even though the electoral system is proportional. ${ }^{8}$ The left bloc includes the Left Party, the Social Democratic Party. The right bloc includes the Moderate Party the Center Party, the Liberal Party, and the Christian Democrats. The Green Party has mostly been positioned outside of the two blocs. Elections are held every fourth year and the election day is fixed to the third Sunday of September. During our sample period, elections were held in 1998, 2002 and 2006. There is no minimum threshold for winning seats in the municipal councils and a number of small, local parties are represented in some of the municipal councils without holding seats in parliament. ${ }^{9}$ When a small local party or the Green Party holds the balance of power in a municipality, it is difficult to classify the majority as either left or right and we treat such cases as undefined. Table 1 gives the frequency of different types of coalitions in the municipalities from 1994 to 2006.

Table 1. Coalitions in Swedish municipalities after 1994 - 2006

\begin{tabular}{llll}
\hline Election period & Left bloc & Right bloc & $\begin{array}{l}\text { Undefined } \\
\text { (Greens holding balance) }\end{array}$ \\
\hline $1994-1998$ & 145 & 65 & $78(30)$ \\
$1998-2002$ & 112 & 93 & $83(20)$ \\
$2002-2006$ & 108 & 99 & $83(20)$
\end{tabular}

Notes: When either of the blocs receives more than 50 percent of the seats the majority coalition is classified accordingly. When neither of the blocs receives 50 percent of the seats the majority coalition is classified as undefined. Cases when either of the blocs would need the support of the Green Party to form a majority are in parentheses in the last column.

The classification of Swedish parties - and their voters - as either left or right, reflects an ideological divide which is clearly discernible in opinions on privatization and municipal outsourcing. ${ }^{10}$ Survey data from the SOM Institute demonstrates that in every single year during our period of study (1998-2006), citizens who support parties in the right bloc are much more in favor of further outsourcing of education, elderly care and health care than citizens who support the left bloc parties. ${ }^{11}$ The supporters of the Moderate Party are the most positive towards outsourcing and the supporters of the Left Party are the most negative. Within the right bloc, the supporters of the Center Party do not express as strong support for outsourcing as the supporters of the other three right parties

\footnotetext{
${ }^{8}$ Sweden is classified as a two-bloc, or bipartisan, system in Alesina et al. (1997), Pettersson-Lidbom (2008), as well as in several other empirical papers.

${ }^{9}$ At the national level there is a 4 percent threshold for winning seats in parliament.

${ }^{10}$ On the general usefulness of left-right terminology, see Bobbio (1996) and Mair (2007).

11 Party support is measured annually by the question "Which party do you like best today?"
} 
do; still Center Party supporters consistently surpass left bloc supporters in their approval of public sector outsourcing. ${ }^{12}$

\section{Trends and patterns in local government outsourcing}

We have assembled a new data set from Statistics Sweden in which we observe outsourcing of several different services in each of Sweden's 290 municipalities over a nine year period (1998-2006). Our data distinguishes outsourcing to private firms, to non-profit organizations and to other units in the public sector. Over the considered period, outsourcing made up 13 percent of the costs for public services in the average Swedish municipality (of which outsourcing to other public entities constitutes 45 percent, and outsourcing to private firms and to non-profit associations constitute 35 and 10 percent respectively.

As a starting point, we demonstrate a fundamental weakness with economic explanations of public sector outsourcing. If transaction costs determine outsourcing, service characteristics should be decisive and we should observe little variation between municipalities and over time. However, our data show that outsourcing as a share of the costs for municipal services has increased by 30 percent from 1998 to 2006.

While such a trend towards more outsourcing in the public sector does not necessarily contradict the Transaction costs model (perhaps in line with the growth of outsourcing and offshoring in the business sector), there are several public services - including preschools and primary education - for which a substantial reduction of transaction costs seem unlikely. It is rather quite suggestive that the trend towards more outsourcing coincides with a political realignment in the municipalities. As described in section 2, the right bloc had a majority in 65 municipalities after the 1994 election. After the 2002 election, this number had increased to 99. Figure 1 displays the coinciding increase in outsourcing and the rise of right majorities in the municipal councils.

\footnotetext{
${ }^{12}$ The SOM surveys are available at The Swedish National Data Service (SND). The data in the SOM surveys were originally collected in a research project at the University of Gothenburg, under the guidance of Sören Holmberg, Lennart Weibull and Lennart Nilsson. Neither SND nor the primary researchers are responsible for the analyses and interpretations presented in this paper. The details of our analyses of the SOM surveys are available upon request.
} 


\section{Figure 1. Development of outsourcing and political majorities}

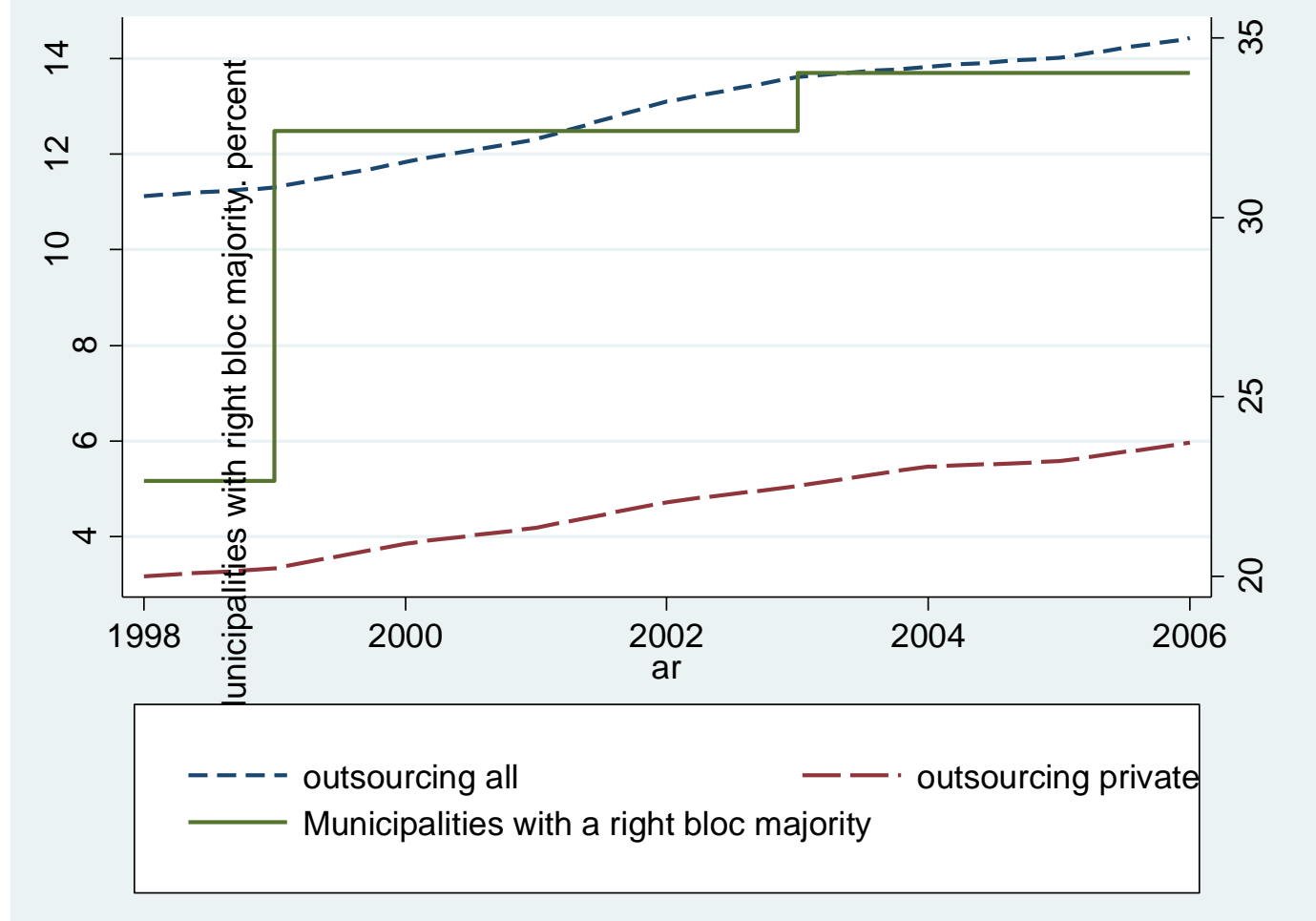

Notes: Costs for outsourcing as a share of the costs for municipal services on the vertical axis to the left. Share of municipalities with a right bloc majority on the vertical axis to the right.

Looking at the cross-section, the use of outsourcing differs considerably between municipalities. While the Transaction costs model cannot account for this, the differences seem to follow a political pattern. The boxplots in Figure 2 summarize outsourcing in Swedish municipalities in 2006. It is evident that municipalities with right majorities are outsourcing more than municipalities with left majorities do. The large spread among right municipalities is another notable difference. On the one hand, several right municipalities produce all or almost all of the depicted services themselves. On the other hand, all of the observations with extremely high values of outsourcing are right municipalities. Finally, an unmistakable difference between preschools and primary education is that the municipalities are more dispersed for preschools with several very high values of outsourcing in right municipalities, whereas the maximum levels for primary education are more similar in left and right municipalities. Figure 2 also contains boxplots for elderly care, which - like preschools - is a service for which municipalities had discretionary control over outsourcing. Since outsourcing varies considerably with political majority for preschools and elderly care but not for primary education, it seems likely that the political preferences of the majority coalition influence outsourcing - when national legislation allow for this. 


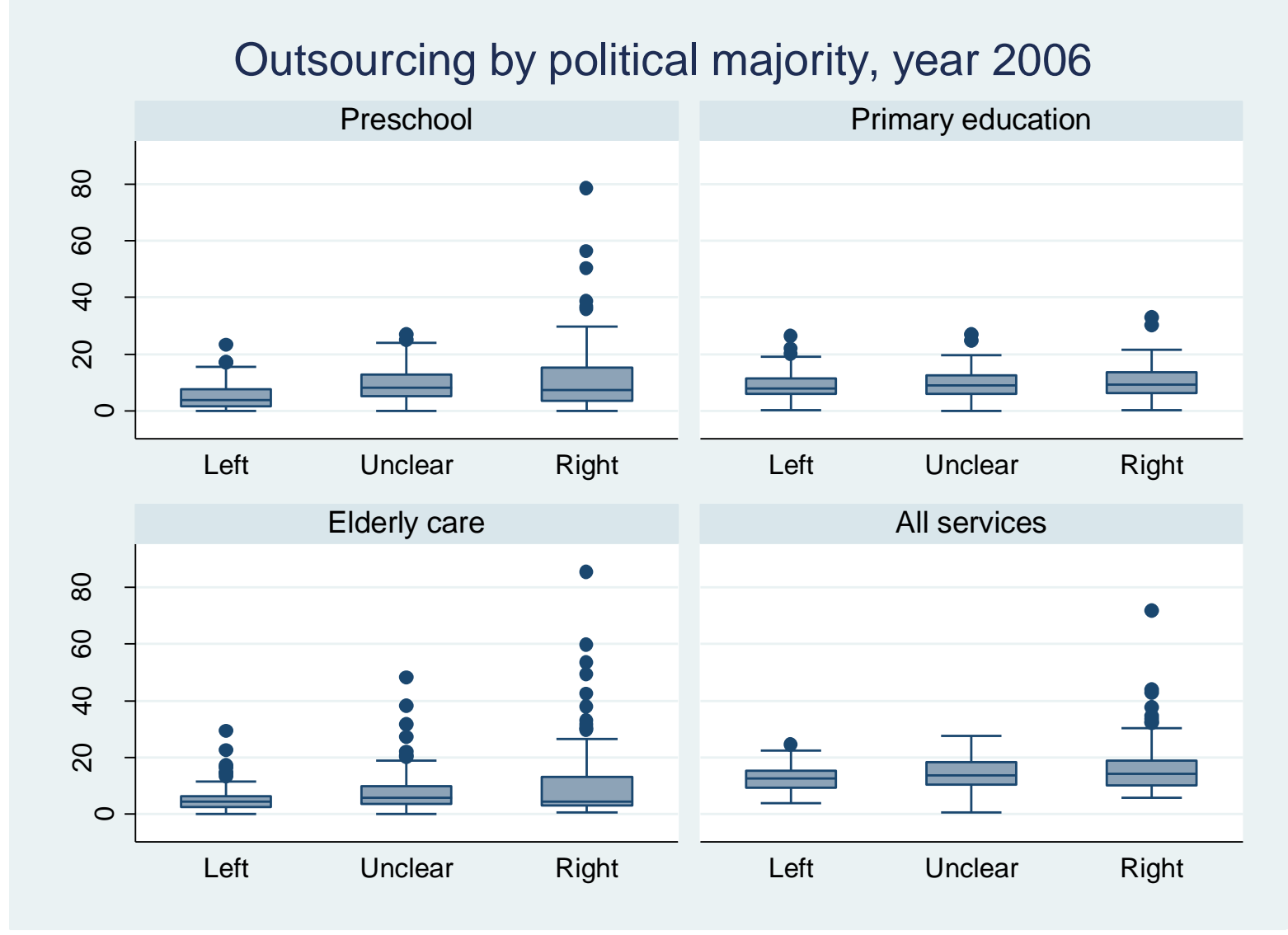

Notes: The boxplots show median (the line in the middle of the box), $1^{\text {st }}$ quartile, and $3^{\text {rd }}$ quartile values (the box itself; thus with a height of 1 interquartile range (IQR)). Lines called whiskers are drawn between the box and the upper and lower adjacent values. The upper adjacent value is defined as the largest data point less than or equal to the $75^{\text {th }}$ percentile $+1.5^{*} \mathrm{IQR}$ and the lower adjacent value is defined as the smallest data point greater than or equal to the $25^{\text {th }}$ percentile $-1.5^{*} \mathrm{IQR}$. Observations above the upper and below the lower adjacent values are plotted as outliers.

Taken together, the trends and patterns of local government outsourcing provide suggestive evidence against economic explanations based on transaction costs. Right majorities outsource more some of them at very high levels - indicating that political models of outsourcing may be more promising. However, more careful testing is required in order to discriminate between different political models.

\section{Identification and testing}

As we have seen, the general pattern in the data hints at political factors as determinants of outsourcing. In order to go on and formally test the relevance of different models of outsourcing, we need to consider several methodological difficulties. First, we need to find proxies for the political determinants of outsourcing. Since the influence of political parties mainly depends on whether or not they are part of the majority coalition, we use a dummy that equals one if the parties in the right bloc hold a majority of the seats in the municipal council. We measure voters' preferences for outsourcing 
by the vote share for the parties in the right bloc in the county election in a municipality. Outsourcing of health care has since long been one of the dominant issues in county elections (health care amounts to 91 percent of total public expenditures at the county level), ${ }^{13}$ and support for outsourcing the county level service health care is strongly correlated with support for outsourcing the municipal level services education and elderly care, according to each of the yearly SOM surveys. ${ }^{14}$ The election year SOM surveys also show that people who voted for any of the right bloc parties are considerably more likely to support further outsourcing of health care, education and elderly care than people who voted for a left bloc party. People who voted for a right bloc party in the county election are also marginally more likely to support outsourcing of health care and education than people who voted for a right bloc party in the municipal election. ${ }^{15}$

Another advantage with a county election measure of political preferences at the municipal level is that county elections are not confounded by strategic behavior of the political parties at the municipal level. As an example of this problem, the Downsian model of electoral competition predicts policy platforms to converge at the ideal point of the median voter, resulting in close municipal election results that are not very informative about voter preferences for outsourcing. Although the Downsian model predicts county elections to be close too, the model doesn't say anything about the closeness of county election results within single municipalities. ${ }^{16}$

A second problem is the risk of obtaining biased estimates when regressing outsourcing shares on political variables. For instance, the transaction costs of outsourcing can arguably be lower in municipalities with a lot of small business owners and a large private sector. Since businessmen and private sector employees are typically more likely to vote for a right bloc party, we run the risk of falsely concluding that outsourcing that is motivated by transaction costs depends on political preferences. The optimal mix of public and private production could also differ between municipalities depending on their size, the composition of their population, and other variables that may be correlated with political preferences; if omitted, such variables will confound our tests of the different models.

The traditional solution to the described selection problem is to add controls for all potentially confounding variables. But doing so is far from easy: data is not available for all variables and it is difficult to know how to correctly specify the model. We address the problem by using a difference-in-

\footnotetext{
${ }^{13}$ Statistics Sweden, Public Finances in Sweden 2008, p. 113.

${ }^{14}$ When measuring opinions of outsourcing on a 1-5 scale where 1 is "Very good suggestion" and 5 is "Very bad suggestion" the correlation coefficient between health care and education is $0.55-0.69$ and the correlation coefficient between health care and elderly care is $0.71-0.80$ in the 1998-2003 SOM surveys (the surveys in which those questions were asked to all respondents). There are no questions about outsourcing of preschools or child care in the SOM surveys.

${ }^{15}$ The shares of right party voters who reported that outsourcing is a "Very good suggestion" or a "Rather good suggestion" differ by about one percentage point between the county and the municipal elections.

${ }^{16}$ On average each county consists of 13.8 municipalities.
} 
differences strategy that relies on the institutional differences between preschools and primary education. In particular we estimate different versions of the following general model:

$$
\begin{aligned}
\text { Out }_{i, t, s}=\alpha+ & \beta_{P} \text { Right }_{i, t} \times \text { Pre }_{s}+\gamma_{P} \text { Votes }_{i, t} \times \text { Pre }_{s}+\beta \text { Right }_{i, t}+\gamma \text { Votes }_{i, t}+\text { Pre }_{s}+\boldsymbol{X}_{i, t} \boldsymbol{\delta}_{\boldsymbol{s}} \\
& +\varepsilon_{i, t, s}
\end{aligned}
$$

Out is a measure of the degree of outsourcing of preschools and primary education. Right is a dummy that equals one if the parties in the right bloc hold a majority of the seats in the municipal council. Votes measures the share of voters in the municipality who voted for a right party in the county election. Pre is a dummy variable for preschool services. Subscript $i, t$ and $s$ are municipality, year and service indicators. We also add the vector $\boldsymbol{X}$ with controls for observable factors that may determine outsourcing. Note that we allow the influence of these factors to be different for outsourcing of preschools and primary education. Finally, $\varepsilon$ is an error term.

Under the assumption that the influence of the political majority and of voter preferences would not differ between outsourcing of preschools and primary education under the same legal framework, we obtain unbiased estimates of the effect of our political variables on outsourcing of preschools relative to primary education $\left(\beta_{P}\right.$ and $\left.\gamma_{P}\right)$; at least conditional on the control function $\boldsymbol{X}_{\boldsymbol{i}, \boldsymbol{t}} \boldsymbol{\delta}_{\boldsymbol{s}}$. This approach accounts for unobservables that vary within municipalities over time (due to for example local market development or learning effects) as long as the influence of these factors is the same for preschools and primary schools. We can account for differences in contracting possibilities between services over time, as long as they are equal for all municipalities, by adding year-service fixed effects to our model. It could still be the case that the relative contracting possibilities for preschools and primary education differ geographically. However, even if we would fail to capture such differences with our control variables, we can account for them by adding county-service fixed effects.

\section{Political models and empirical parameters}

The four models we want to test give different predictions for the parameters $\beta_{P}$ and $\gamma_{P}$. Before we explain the predictions in detail, it is worth repeating that our approach relies on a legal framework that gave local politicians discretionary power to decide about outsourcing of preschools, whereas they had limited influence over the share of private providers in primary education. Next, we describe four different accounts of outsourcing that follow from four relevant theoretical models: the Transaction costs model, the Patronage model, the Downsian median voter model, and the Citizen candidate model. Table 2 at the end of the section summarizes the predictions of the four models. 


\section{The Transaction costs model}

As the name indicates the Transaction costs model predicts that the transaction costs of outsourcing will determine the make-or-buy-decision. Services with low transaction costs will be outsourced, whereas services that are difficult to contract on will be produced in-house. The difficulty of contracting, in turn, depends on the difficulty of measuring and monitoring quality, the need for flexibility, and the risk that "specific assets" give rise to hold-up problems. ${ }^{17}$ An implicit assumption is that policy makers maximize social welfare. The political party, ideology, or self-interest of voters and politicians are immaterial.

If this model is correct, we expect: $\beta_{P}=0$ since the identity of the majority coalition do not matter. When it comes to vote shares, we note that the share of primary education that is produced by private providers is determined on a quasi-market of school choice. Since parents do not internalize full transaction costs (not even in this model), we expect their demand for private schools to be correlated with their political preferences. ${ }^{18}$ In terms of our empirical specification, we expect $\gamma>0$. However, the political preferences of the electorate should not influence the outsourcing decision of the politicians. We therefore expect $\gamma_{P}=-\gamma<0$.

\section{The Patronage model}

In the Patronage model, politicians are motivated by and compete for office. The distinguishing feature of the model is that politicians prefer in-house production by public employees. The private benefits to politicians of public employment include "the support of local public sector unions, the opportunity to purchase supplies from political allies, the ability to hire relatives and campaign activists, the ability to use local government employees on political projects, etc" (Lopez-de-Silanes, Shleifer and Vishny 1997: 450). ${ }^{19}$ Thus, all parties, independently of their political color, prefer inhouse production to outsourcing and we expect $\beta_{P}=0$. However, voters realize that governments may over use public employees and thus oust a government if it is misusing its power. Patronage has to be paid for by higher taxes, which is something voters generally dislike. When there is strong political competition the government finds it more difficult to satisfy a majority of voters and may need to use more outsourcing to reduce taxes. When elections are competitive, voters' preferences for outsourcing can thus be expected to matter for preschools. But since the demand for private schools is probably

\footnotetext{
${ }^{17}$ See Levin and Tadelis (2010) for a comprehensive theoretical account of the Transaction costs model.

${ }^{18}$ The positive association between support for the right bloc of parties and support for further outsourcing of education (which we reported in section 2) does not differ much between parents and non-parents. In addition, an opinion survey conducted by Demoskop in 2001 reported that 35 percent of parents with children in a private school would vote for one of the right bloc parties, whereas the same figure for parents who had chosen a public school for their children was 24 percent (Bergmark 2001: 33).

${ }^{19}$ The Patronage model of government outsourcing is similar to the theory developed by Boycko, Shleifer and Vishny (1995) on the privatization of state-owned enterprises,
} 
also positively correlated with right votes, we cannot expect anything else than $\gamma_{P} \approx 0$. This logic and prediction is the same for the other two political models below (Downsian and Citizen candidate). In non-competitive elections, however, voters' preferences do not matter for outsourcing of preschools and we expect $\gamma_{P}<0$ (due to the positive relationship between right votes and primary schools).

We identify competitive elections as elections in which the right bloc obtains between 45 and 55 percent of the votes; we set the dummy Competitive equal to one when this is the case. Again, note that we measure voters' preferences for outsourcing by the vote share for the right bloc within a municipality in the county election, whereas we measure competitiveness by the same votes share in the municipal election.

To test the Patronage model, we include the dummy Competitive, an interaction between Competitive and right votes in the county election (Votes), an interaction between Competitive and the preschool dummy (Pre), and finally the interaction between all three variables. The Patronage model predicts the parameter of the triple interaction to be negative, since the voters' preferences for outsourcing should only influence outsourcing for preschools when elections are close.

\section{The Downsian median voter model}

The Downsian model (Downs 1957) shares with the Patronage model the assumption that politicians are office motivated. Politicians have to propose the policy preferred by the median voter to stand a chance of winning. Thus, the political color of the local majority does not influence policy, and we expect $\beta_{P}=\beta=0 .{ }^{20}$ The preference distribution among voters matter, however. As mentioned, policy is determined by the preferences of the median voter. Since the median voter's preferred position is likely to be strongly correlated with mean position, we expect a positive relationship of the share of votes for right wing parties in the county elections on the outsourcing of preschools. ${ }^{21}$ Since national legislation effectively lets parents determine the outsourcing of primary education, we expect $\gamma>0$. Unfortunately, since we expect the share of votes to have a positive, but not necessarily an equal, effect both for preschools and for primary education, it is difficult to determine the sign of $\gamma_{P}$. The sign depends on how the median voter's preferences for outsourcing differ from the mean parent's. In general it would be unwarranted to assume any difference without an empirical examination of the case. We therefore expect $\gamma_{P} \approx 0$

\section{The Citizen candidate model}

In the Citizen candidate model of Osborne and Slivinsky (1996) and Besley and Coate (1997), politicians are motivated by the chance to implement their own preferred policy. Hence, we expect

\footnotetext{
${ }^{20}$ The probabilistic voting model is similar to the Downsian model in that it predicts convergence, but its focus on explaining spending on different groups deviates from our focus in this paper.

${ }^{21}$ Note that it would be problematic to use vote shares from municipal elections to measure voter preferences for outsourcing since the model predicts a 50-50 vote split regardless of the distribution of preferences.
} 
$\beta_{P}>0$, since politicians from parties to the right typically have a preference for more outsourcing than left politicians do, and since the model predicts that two candidates at equidistant points from the median voter's preferred position will run for office - one of whom will win the election. The distribution of preferences in the electorate determines the candidates who have sufficient incentives to run for office, and hence the policy preferences of the competing candidates. Again, we expect that $\gamma$ is positive, given that parents who vote for parties to the right are more inclined to choose a private school for their children. The sign of $\gamma_{P}$ is difficult to predict, but is determined by the same logic as for the Downsian model. The distinguishing prediction of the Citizen candidate model is $\beta_{P}>0$.

Table 2. Predictions

\begin{tabular}{lcc}
\hline Model & $\beta_{P}$ & $\gamma_{P}$ \\
\hline Transaction cost & 0 & $<0$ \\
Downs & 0 & $\approx 0$ \\
Patronage (Non competitive) & 0 & $<0$ \\
Patronage (Competitive) & 0 & $\approx 0$ \\
Citizen candidate & $>0$ & $\approx 0$ \\
\hline
\end{tabular}

\section{Results}

We now turn to the estimations of the empirical models and the formal testing of the theoretical predictions. Table 3 shows the estimates of the parameters with outsourcing to all providers as the dependent variable. The specifications in columns 1-3 differ according to whether we include control variables that capture differences in economic and demographic structure (see detailed regression results in Appendix A and description of variables in Appendix B), year dummies, and county fixed effects (all also interacted with the preschool dummy). ${ }^{22}$ Column 4 present results from a specification that we use to test the Patronage model. ${ }^{23}$

\footnotetext{
${ }^{22}$ Tables A1 and A2 in Appendix A contain all of the estimates including for the control variables.

${ }^{23} 287$ of Sweden's 290 municipalities are included in the regressions. We exclude two municipalities that were founded during our sample period (Nykvarn and Knivsta). We are also missing outsourcing data for one municipality (Upplands Väsby).
} 
Table 3. Estimates of outsourcing of preschools and primary schools

\begin{tabular}{|c|c|c|c|c|}
\hline \multicolumn{5}{|c|}{ Dep. var: Outsourcing (all providers, share of budget) } \\
\hline & (1) & (2) & (3) & (4) \\
\hline Right $\times \operatorname{Pre}\left(\beta_{\mathrm{P}}\right)$ & $1.603^{* * * *}$ & $1.581 * * *$ & $1.429 * * *$ & $1.389^{* *}$ \\
\hline & $(0.374)$ & $(0.369)$ & $(0.359)$ & $(0.369)$ \\
\hline Votes $\times \operatorname{Pre}\left(\gamma_{\mathrm{P}}\right)$ & 0.0233 & $0.0564 * *$ & $0.0870 * * *$ & $0.0769 * * *$ \\
\hline & $(0.0217)$ & $(0.0238)$ & $(0.0253)$ & $(0.0259)$ \\
\hline Pre & $-45.44 * * *$ & $-42.38 * * *$ & $-39.63 * * *$ & $-37.62 * * *$ \\
\hline & (7.655) & (7.485) & $(8.566)$ & $(8.439)$ \\
\hline Right & $0.388^{*}$ & $0.388^{*}$ & 0.112 & 0.134 \\
\hline & $(0.234)$ & $(0.234)$ & $(0.237)$ & $(0.237)$ \\
\hline Votes & $0.0254 * *$ & $0.0320 * *$ & 0.00107 & 0.00176 \\
\hline & $(0.0129)$ & $(0.0137)$ & $(0.0145)$ & (0.0148) \\
\hline Votes $\times$ Pre $\times$ competitive & & & & $\begin{array}{c}-0.0717 \\
(0.0458)\end{array}$ \\
\hline Votes $\times$ competitive & & & & $0.0881 * * *$ \\
\hline Competitive $\times$ Pre & & & & $\begin{array}{c}3.042 \\
(2.213)\end{array}$ \\
\hline Competitive & & & & $\begin{array}{c}-3.922 * * * \\
(1.360)\end{array}$ \\
\hline Constant & $\begin{array}{c}4.891 \\
(4.670)\end{array}$ & $\begin{array}{c}5.985 \\
(4.764)\end{array}$ & $\begin{array}{c}12.02 * * \\
(5.384)\end{array}$ & $\begin{array}{c}11.13 * * \\
(5.372)\end{array}$ \\
\hline Controls & Yes & Yes & Yes & Yes \\
\hline Controls $\times$ Pre & Yes & Yes & Yes & Yes \\
\hline Year fixed effects & - & Yes & Yes & Yes \\
\hline Year fixed effect $\times$ Pre & - & Yes & Yes & Yes \\
\hline County fixed effects & & & Yes & Yes \\
\hline County fixed effects $\times$ Pre & & & Yes & Yes \\
\hline Observations & 5128 & 5128 & 5128 & 5128 \\
\hline Municipalities & 287 & 287 & 287 & 287 \\
\hline
\end{tabular}

Robust standard errors in parentheses. *** $\mathrm{p}<0.01, * * \mathrm{p}<0.05, * \mathrm{p}<0.1$

Notably, the coefficient for Right $\times \operatorname{Pre}\left(\beta_{\mathrm{P}}\right)$ is positive and statistically significant in all columns. The interpretation is that municipalities with a right majority are outsourcing relatively more of preschools than of primary schools. This result is only consistent with the Citizen candidate model; the other models all predicts $\beta_{\mathrm{P}}=0$. The size of the effect is economically significant, given the ideological preferences of the electorate, the average right government is outsourcing about 1.5 percentage points more of preschools than of primary schools (the average outsourcing share over the period is 7.1 both for preschools and primary schools).

Note that the estimated effects are for a right majority relative to a left or an undefined majority. The choice to look at right majorities vs. left and undefined majorities or left vs. right and undefined is largely arbitrary. Results for the latter specification is presented in Appendix A, Table A3, and show that left majorities are outsourcing less of preschools relative to primary schools.

The other coefficient of interest, for Votes $\times \operatorname{Pre}\left(\gamma_{\mathrm{P}}\right)$, is also positive and statistically significant in all but column 1. This is inconsistent with the Transaction costs and Patronage model (in noncompetitive elections), which predict $\gamma_{\mathrm{P}}<0$. The effect of voter preferences for outsourcing appears quite weak. A ten percentage point increase in the vote share for the parties in the right bloc -i.e. a 
very large increase - increases the outsourcing of preschools relative to primary education with only 0.9 percentage points.

The specification in column 4 investigates if the relationship between votes and outsourcing differs between competitive and non-competitive elections. The Patronage model predicts that this relationship should be negative when elections are non-competitive but non-existent when elections are competitive. The intuition is that competitive elections discipline politicians so that they have to pick similar levels of outsourcing of preschools as parents have themselves demanded for outsourcing of primary schools. The estimates in column 4 do not support the view that the competitiveness of elections matters for municipal outsourcing.

Table 4 contains estimates from specifications where the dependent variable is outsourcing to private providers. The estimates are smaller both for Right $x$ Pre $\left(\beta_{\mathrm{P}}\right)$ and for Votes $x$ Pre $\left(\gamma_{\mathrm{P}}\right)$, but choices of private outsourcing do not seem to differ markedly from outsourcing choices within the public sector.

Table 4. Estimates of outsourcing of preschools and primary schools to private entities Dep. Var: Outsourcing (private proviuders, share of budget)

\begin{tabular}{|c|c|c|c|c|}
\hline & (1) & $(2)$ & (3) & (4) \\
\hline \multirow[t]{2}{*}{ Right $\times$ Pre $\left(\beta_{\mathrm{P}}\right)$} & $0.615^{* *}$ & $0.617 * *$ & $0.572 * *$ & $0.728 * * *$ \\
\hline & $(0.289)$ & $(0.274)$ & $(0.278)$ & $(0.281)$ \\
\hline \multirow{2}{*}{ Votes $\times \operatorname{Pre}\left(\gamma_{\mathrm{P}}\right)$} & 0.00266 & $0.0433 * *$ & $0.0503 * *$ & $0.0576 * *$ \\
\hline & $(0.0172)$ & $(0.0192)$ & $(0.0217)$ & $(0.0228)$ \\
\hline \multirow[t]{2}{*}{ Pre } & $-26.95 * * *$ & $-22.03 * * *$ & $-27.29 * * *$ & $-24.83 * * *$ \\
\hline & $(6.426)$ & $(6.025)$ & $(6.997)$ & $(6.926)$ \\
\hline \multirow[t]{2}{*}{ Right } & 0.297 & $0.301 *$ & 0.0994 & 0.134 \\
\hline & $(0.184)$ & $(0.182)$ & $(0.184)$ & $(0.187)$ \\
\hline \multirow[t]{2}{*}{ Votes } & $0.0163^{*}$ & $0.0212 * *$ & 0.0149 & 0.0103 \\
\hline & $(0.00968)$ & $(0.0102)$ & $(0.0114)$ & $(0.0119)$ \\
\hline Votes $\times$ Pre $\times$ competitive & & & & $\begin{array}{c}-24.83 * * * \\
(6.926)\end{array}$ \\
\hline \multirow[t]{2}{*}{ Votes $\times$ competitive } & & & & $0.0611 * *$ \\
\hline & & & & $(0.0260)$ \\
\hline \multirow[t]{2}{*}{ Competitive $\times$ Pre } & & & & 1.360 \\
\hline & & & & $(1.769)$ \\
\hline \multirow[t]{2}{*}{ Competitive } & & & & $-3.050 * *$ \\
\hline & & & & $(1.252)$ \\
\hline \multirow[t]{2}{*}{ Constant } & -0.941 & 0.0713 & $7.511^{*}$ & $8.071 *$ \\
\hline & $(7.595)$ & $(7.674)$ & $(4.198)$ & $(4.203)$ \\
\hline Controls & Yes & Yes & Yes & Yes \\
\hline Controls $\times$ Pre & Yes & Yes & Yes & Yes \\
\hline Year fixed effects & - & Yes & Yes & Yes \\
\hline Year fixed effect $\times$ Pre & - & Yes & Yes & Yes \\
\hline County fixed effects & & & Yes & Yes \\
\hline County fixed effects $\times$ Pre & & & Yes & Yes \\
\hline Observations & 5120 & 5120 & 5120 & 5120 \\
\hline Municipalities & 287 & 287 & 287 & 287 \\
\hline
\end{tabular}




\section{Concluding remarks}

The presented evidence is consistent with a political view of government outsourcing as outlined in the Citizen candidate model. Other economic and political models (the Transaction cost, the Patronage, and the Downsian model) are inconsistent both with the general development of outsourcing in the Swedish public sector and with our estimates based on comparisons between preschools and primary education.

Our result stands in contrast to previous studies in other countries, which have mostly concluded that political preferences are unrelated to outsourcing

Although our data (with variation between municipalities and over time as well as between services) trumps what have been used previously, data availability and sample size still impose limitations on the empirical analysis. As for now and given the data at hand, the political preferences of the ruling majority seem to be important in explaining public sector outsourcing. 


\section{References}

Alesina, A., Roubini, N. and G. Cohen, 1997. Political Cycles and the Macroeconomy. Cambridge: MIT Press.

Andersson, F. and H. Jordahl, 2011. Outsourcing public services: Ownership, competition, quality and contracting. IFN Working Paper, No. 874. Research Institute of Industrial Economics (IFN).

Bel, G. and X. Fageda, 2007. Why do local governments privatise public services? A survey of empirical studies, Local Government Studies, 33 (4), 517-534.

Bel, G. and X. Fageda, 2009. Factors explaining local privatization: a meta-regression analysis. Public Choice, 139 (1), 105-119.

Bergmark, K., 2001. Föräldrar med barn i friskola och kommunal skola. Svenskt Näringsliv.

Bhatti, Y., A Olsen, and L. Pedersen, 2009. The effects of administrative professionals on contracting out. Governance, 22 (1), 121-137.

Bobbio, N., 1996. Left \& Right: The Significance of a Political Distinction. Cambridge, UK: Polity Press.

Besley, T. and S. Coate, 1997. An economic model of representative democracy. Quarterly Journal of Economics, 112 (1), 85-114.

Böhlmark, A. and M. Lindahl, 2008. Does school privatization improve educational achievement? Evidence from Sweden's voucher reform. IZA Discussion Paper No. 3691

Boycko, M., A. Shleifer and R. Vishny, 1996. A theory of privatisation. Economic Journal, 106 (435), 309-319.

Brown, T. and M. Potoski, 2003. The influence of transactions costs on municipal and county government choices of alternative modes of service provision. Journal of Public Administration Research and Theory, 13(4), 441-468.

Coase, R., 1937. The nature of the firm. Econometrica, 4, 386-405.

Dijkgraaf, E., R. H. J. M. Gradus \& B. Melenberg, 2003. Contracting out refuse collection. Empirical Economics, 28 (3), 553-570.

Downs, A., 1957. An Economic Theory of Democracy. New York: Harper and Row Publishers.

Grossman, S. and O. Hart, 1986. The costs and benefits of ownership: A theory of vertical and lateral integration. Journal of Political Economy, 94 (4), 691-719.

Hart, O., A. Shleifer and R. Vishny, 1997. The proper scope of government: Theory and an application to prisons. Quarterly Journal of Economics, 112 (4), 1127-1161.

Levin, J. and S. Tadelis, 2010. Contracting for government services: Theory and evidence from U.S. cities. Journal of Industrial Economics, 58 (3), 507-541.

Lopez-de-Silanes, F., A. Shleifer and R. Vishny, 1997. Privatization in the United States. Rand Journal of Economics 28, 447-71.

Mair, P., 2007. Left-right orientations. In R. Dalton and H-D Klingemann (eds), The Oxford Handbook of Political Behavior. Oxford: Oxford University Press. 
McGuire, R., R. Ohsfeldt, and N. van Cott, 1987. The determinants of the choice between public and private production of a publicly funded service. Public Choice, 54 (3), 211-230.

Ohlsson, H., 2003. Ownership and production costs. Choosing between public production and contracting-out in the case of Swedish refuse collection. Fiscal Studies, 24, 451-476.

Osborne, M. and A. Slivinski, 1996. A model of political competition with citizen-candidates. Quarterly Journal of Economics, 111 (1), 65-96.

Pettersson-Lidbom, P., 2008. Do parties matter for economic outcomes? A regression-discontinuity approach. Journal of the European Economic Association, 6 (5), 1037-1056.

Statistics Sweden, 2009. Public Finances in Sweden 2009.

Swedish National Agency for Education, 2006. Descriptive data on pre-school activities, school-age childcare, schools and adult education in Sweden 2006. Swedish National Agency for Education report no. 283.

Williamson, O., 1981. The economics of organization. American Journal of Sociology, 87, 548-577.

Williamson, O., 1985. The Economic Institutions of Capitalism. New York: Free Press.

Zullo, R., 2009. Does fiscal stress induce privatization? Correlates of private and intermunicipal contracting, 1992-2002. Governance, 22 (3), 459-481. 


\section{Appendix A. Detailed and additional regression results}

Table A1. Detailed estimates of outsourcing of primary education and preschools

\begin{tabular}{|c|c|c|c|c|}
\hline \multicolumn{5}{|c|}{ Dep. Var: Outsourcing (all providers, share of budget) } \\
\hline Right $x$ PS $\left(\beta_{\mathrm{P}}\right)$ & $1.603^{* *}$ & $1.581 * *$ & $1.429 * *$ & $1.389 * * *$ \\
\hline & $(0.693)$ & $(0.697)$ & $(0.673)$ & $(0.369)$ \\
\hline Votes $\mathrm{x}$ PS & 0.0233 & $0.0564 * *$ & $0.0870^{* * *}$ & $0.0769 * * *$ \\
\hline & $(0.0422)$ & $(0.0453)$ & $(0.0485)$ & $(0.0259)$ \\
\hline PS & $-45.44 * * *$ & $-42.38 * * *$ & $-39.63^{* * *}$ & $-37.62 * * *$ \\
\hline & $(15.94)$ & $(15.81)$ & (18.84) & $(8.439)$ \\
\hline Right & $0.388^{*}$ & $0.388^{*}$ & 0.112 & 0.134 \\
\hline & $(0.529)$ & $(0.530)$ & $(0.500)$ & $(0.237)$ \\
\hline Votes & $0.0254 * *$ & $0.0320 * *$ & 0.00107 & 0.00176 \\
\hline & $(0.0293)$ & $(0.0317)$ & $(0.0314)$ & $(0.0148)$ \\
\hline Votes $\mathrm{x}$ PS $\mathrm{x}$ competitive & & & & $\begin{array}{l}-0.0717 \\
(0.0458)\end{array}$ \\
\hline Votes $\mathrm{x}$ competitive & & & & $\begin{array}{c}0.0881 \text { **** } \\
(0.0281)\end{array}$ \\
\hline Competitive x PS & & & & $\begin{array}{c}3.042 \\
(2.213)\end{array}$ \\
\hline Competitive & & & & $\begin{array}{c}-3.922 * * * \\
(1.360)\end{array}$ \\
\hline Employment & $\begin{array}{c}-0.229 * * * \\
(0.0592)\end{array}$ & $\begin{array}{c}-0.247 * * * \\
(0.0620)\end{array}$ & $\begin{array}{c}-0.279 * * * \\
(0.0678)\end{array}$ & $\begin{array}{c}-0.297 * * * \\
(0.0677)\end{array}$ \\
\hline Business employment & $\begin{array}{c}0.0528 * * * \\
(1.213)\end{array}$ & $\begin{array}{c}0.0591 * * * \\
(1.244)\end{array}$ & $\begin{array}{c}0.0701 * * * * \\
(1.229)\end{array}$ & $\begin{array}{c}0.0676^{* * * *} \\
(1.242)\end{array}$ \\
\hline Tax base & $\begin{array}{c}0.0926 * * * \\
(0.00881)\end{array}$ & $\begin{array}{c}0.121 * * * \\
(0.0170)\end{array}$ & $\begin{array}{c}0.0288 \\
(0.0186)\end{array}$ & $\begin{array}{c}0.0654 \text { **** } \\
(0.0181)\end{array}$ \\
\hline Municipal net profit/loss & $\begin{array}{c}1.33 \mathrm{e}-05 \\
(4.26 \mathrm{e}-05)\end{array}$ & $\begin{array}{c}2.07 \mathrm{e}-05 \\
(4.29 \mathrm{e}-05)\end{array}$ & $\begin{array}{c}2.46 \mathrm{e}-05 \\
(3.50 \mathrm{e}-05)\end{array}$ & $\begin{array}{c}3.18 \mathrm{e}-05 \\
(3.49 \mathrm{e}-05)\end{array}$ \\
\hline Grants & $\begin{array}{c}0.000277 * * * \\
(3.21 \mathrm{e}-05)\end{array}$ & $\begin{array}{c}0.000354 * * * \\
(4.23 \mathrm{e}-05)\end{array}$ & $\begin{array}{c}0.000294 * * * \\
(5.69 \mathrm{e}-05)\end{array}$ & $\begin{array}{c}0.000396 * * * \\
(5.87 \mathrm{e}-05)\end{array}$ \\
\hline University education ( $3>=$ years) & $\begin{array}{c}0.305 * * * \\
(0.0598)\end{array}$ & $\begin{array}{c}0.261 * * * \\
(0.0655)\end{array}$ & $\begin{array}{c}0.434 * * * \\
(0.0643)\end{array}$ & $\begin{array}{c}0.357 * * * \\
(0.0626)\end{array}$ \\
\hline Preschool children ( $<7$ years, percent) & $\begin{array}{l}-0.112 \\
(0.146)\end{array}$ & $\begin{array}{l}-0.264 \\
(0.191)\end{array}$ & $\begin{array}{c}-0.611 * * * \\
(0.192)\end{array}$ & $\begin{array}{c}-0.438 * * \\
(0.183)\end{array}$ \\
\hline School age children ( 7 to 16 , percent) & $\begin{array}{l}-0.0318 \\
(0.126)\end{array}$ & $\begin{array}{l}-0.105 \\
(0.143)\end{array}$ & $\begin{array}{l}0.0868 \\
(0.131)\end{array}$ & $\begin{array}{l}-0.124 \\
(0.126)\end{array}$ \\
\hline Old $(>=65$ years $)$ & $\begin{array}{c}-0.285^{* * *} \\
(0.0761)\end{array}$ & $\begin{array}{c}-0.366 * * * \\
(0.0832)\end{array}$ & $\begin{array}{c}-0.265^{* * *} \\
(0.0886)\end{array}$ & $\begin{array}{c}-0.315^{* * * *} \\
(0.0878)\end{array}$ \\
\hline Foreign citizens & $\begin{array}{c}0.0503 \\
(0.0377)\end{array}$ & $\begin{array}{c}0.0317 \\
(0.0382)\end{array}$ & $\begin{array}{c}-0.104 * * * \\
(0.0399)\end{array}$ & $\begin{array}{c}-0.116^{* * * *} \\
(0.0406)\end{array}$ \\
\hline On welfare & $\begin{array}{l}-0.0223 \\
(0.0813)\end{array}$ & $\begin{array}{l}-0.0583 \\
(0.0820)\end{array}$ & $\begin{array}{c}-0.258 * * * \\
(0.0847)\end{array}$ & $\begin{array}{c}-0.257 * * * \\
(0.0851)\end{array}$ \\
\hline Interactions with preschool dummy & & & & \\
\hline Employment & $\begin{array}{l}-0.0104 \\
(0.0978)\end{array}$ & $\begin{array}{r}-0.0751 \\
(0.105)\end{array}$ & $\begin{array}{l}0.0440 \\
(0.122)\end{array}$ & $\begin{array}{l}0.0692 \\
(0.117)\end{array}$ \\
\hline Business employment & $\begin{array}{c}0.0496 * * \\
(2.220)\end{array}$ & $\begin{array}{c}0.0657 * * * \\
(2.363)\end{array}$ & $\begin{array}{c}0.0565 * * \\
(2.636)\end{array}$ & $\begin{array}{c}0.0616^{* * *} \\
(2.627)\end{array}$ \\
\hline Tax base & $\begin{array}{l}-0.0222 \\
(0.0156)\end{array}$ & $\begin{array}{c}0.0779 * * \\
(0.0368)\end{array}$ & $\begin{array}{c}0.0452 \\
(0.0379)\end{array}$ & $\begin{array}{l}-0.0244 \\
(0.0151)\end{array}$ \\
\hline Municipal profit/loss & $\begin{array}{l}-3.62 \mathrm{e}-05 \\
(6.73 \mathrm{e}-05)\end{array}$ & $\begin{array}{l}-8.99 \mathrm{e}-06 \\
(6.71 \mathrm{e}-05)\end{array}$ & $\begin{array}{l}-4.29 e-05 \\
(6.13 e-05)\end{array}$ & $\begin{array}{l}-5.57 \mathrm{e}-05 \\
(6.03 \mathrm{e}-05)\end{array}$ \\
\hline Grants & $\begin{array}{c}-0.000217 * * * \\
(6.02 \mathrm{e}-05)\end{array}$ & $\begin{array}{c}6.15 \mathrm{e}-05 \\
(7.25 \mathrm{e}-05)\end{array}$ & $\begin{array}{c}-0.000175^{*} \\
(9.60 \mathrm{e}-05)\end{array}$ & $\begin{array}{c}-0.000376 * * * \\
(7.47 \mathrm{e}-05)\end{array}$ \\
\hline University education $(3>=$ years $)$ & $\begin{array}{c}0.864 * * * \\
(0.101)\end{array}$ & $\begin{array}{c}0.628 * * * \\
(0.100)\end{array}$ & $\begin{array}{c}0.517 * * * * \\
(0.103)\end{array}$ & $\begin{array}{l}0.672 * * * \\
(0.0975)\end{array}$ \\
\hline Preschool children ( $<7$ years, percent) & $\begin{array}{c}2.122 * * * \\
(0.259)\end{array}$ & $\begin{array}{c}2.112 * * * \\
(0.320)\end{array}$ & $\begin{array}{c}2.038 * * * \\
(0.322)\end{array}$ & $\begin{array}{c}1.681 \text { *** } \\
(0.251)\end{array}$ \\
\hline School age children ( 7 to 16 , percent) & $\begin{array}{c}0.682 * * * \\
(0.210)\end{array}$ & $\begin{array}{c}0.113 \\
(0.221)\end{array}$ & $\begin{array}{c}0.215 \\
(0.217)\end{array}$ & $\begin{array}{c}0.651 * * * \\
(0.194)\end{array}$ \\
\hline Old $(>=65$ years $)$ & $\begin{array}{c}0.718 * * * \\
(0.128)\end{array}$ & $\begin{array}{c}0.472 * * * \\
(0.125)\end{array}$ & $\begin{array}{c}0.650 * * * \\
(0.137)\end{array}$ & $\begin{array}{c}0.750^{* * * *} \\
(0.130)\end{array}$ \\
\hline Foreign citizens & $\begin{array}{c}0.0277 \\
(0.0551)\end{array}$ & $\begin{array}{l}-0.0615 \\
(0.0570)\end{array}$ & $\begin{array}{l}-0.0558 \\
(0.0712)\end{array}$ & $\begin{array}{l}-0.0302 \\
(0.0702)\end{array}$ \\
\hline On welfare & $\begin{array}{c}0.414 * * * \\
(0.123)\end{array}$ & $\begin{array}{c}0.334 * * * \\
(0.122)\end{array}$ & $\begin{array}{c}0.491 \text { *** } \\
(0.137)\end{array}$ & $\begin{array}{c}0.489 * * * \\
(0.135)\end{array}$ \\
\hline Constant & $\begin{array}{c}4.891 \\
(4.670)\end{array}$ & $\begin{array}{c}5.985 \\
(4.764)\end{array}$ & $\begin{array}{c}12.02 * * \\
(5.384)\end{array}$ & $\begin{array}{l}11.13^{* *} \\
(5.372)\end{array}$ \\
\hline Year fixed effects & - & Yes & Yes & Yes \\
\hline Year fixed effect $\mathrm{x}$ preschool & - & Yes & Yes & Yes \\
\hline County fixed effects & & & Yes & Yes \\
\hline County fixed effects x preschool & & & Yes & Yes \\
\hline Observations & 5128 & 5128 & 5128 & 5128 \\
\hline Municipalities & 287 & 287 & 287 & 287 \\
\hline R-squared & 0.430 & 0.447 & 0.517 & 0.515 \\
\hline
\end{tabular}

Robust standard errors in parentheses. ${ }^{* *} \mathrm{p}<0.01, * * \mathrm{p}<0.05, * \mathrm{p}<0.1$. 
Table A2. Detailed estimates of outsourcing of primary education and preschools to private entities

\begin{tabular}{|c|c|c|c|c|}
\hline \multicolumn{5}{|c|}{ Dep. Var: Outsourcing (all providers, share of budget) } \\
\hline & (1) & (2) & (3) & (4) \\
\hline \multirow[t]{2}{*}{ Right $x$ PS $\left(\beta_{\mathrm{P}}\right)$} & 0.615 & 0.617 & $0.572 * *$ & $0.728 * * *$ \\
\hline & $(0.465)$ & $(0.446)$ & $(0.278)$ & $(0.281)$ \\
\hline \multirow{2}{*}{ Votes x PS } & 0.00266 & 0.0433 & $0.0503 * *$ & $0.0576 * *$ \\
\hline & $(0.0344)$ & $(0.0349)$ & $(0.0217)$ & $(0.0228)$ \\
\hline \multirow[t]{2}{*}{ PS } & $-26.95^{* *}$ & $-22.03 *$ & $-27.29 * * *$ & $-24.83^{* * *}$ \\
\hline & $(12.52)$ & $(11.89)$ & $(6.997)$ & $(6.926)$ \\
\hline \multirow[t]{2}{*}{ Right } & 0.297 & 0.301 & 0.0994 & 0.134 \\
\hline & $(0.396)$ & $(0.394)$ & $(0.184)$ & $(0.187)$ \\
\hline \multirow[t]{2}{*}{ Votes } & 0.0163 & 0.0212 & 0.0149 & 0.0103 \\
\hline & $(0.0216)$ & $(0.0235)$ & $(0.0114)$ & $(0.0119)$ \\
\hline Votes $\mathrm{x}$ PS $\mathrm{x}$ competitive & & & & $\begin{array}{c}-24.83 * * * \\
(6.926)\end{array}$ \\
\hline \multirow[t]{2}{*}{ Votes $\mathrm{x}$ competitive } & & & & $0.0611 * *$ \\
\hline & & & & $(0.0260)$ \\
\hline \multirow[t]{2}{*}{ Competitive x PS } & & & & 1.360 \\
\hline & & & & $(1.769)$ \\
\hline \multirow[t]{2}{*}{ Competitive } & & & & $-3.050 * *$ \\
\hline & & & & $(1.252)$ \\
\hline Employment & -0.0928 & -0.110 & $-0.183 * * *$ & $-0.189 * * *$ \\
\hline & $(0.100)$ & $(0.109)$ & $(0.0564)$ & $(0.0564)$ \\
\hline Business employment & $0.0552 * *$ & $0.581 * *$ & $0.0748 * * *$ & $0.0757 * * *$ \\
\hline & $(2.277)$ & $(2.459)$ & $(0.0116)$ & $(0.0117)$ \\
\hline Tax base & $0.0561 * * *$ & $0.0718^{* *} *$ & 0.0156 & 0.0159 \\
\hline & $(0.0139)$ & $(0.0344)$ & $(0.0146)$ & $(0.0144)$ \\
\hline Municipal net profit/loss & $2.11 \mathrm{e}-05$ & $2.41 \mathrm{e}-05$ & $3.28 \mathrm{e}-05$ & $3.35 \mathrm{e}-05$ \\
\hline & $(3.54 \mathrm{e}-05)$ & $(3.66 \mathrm{e}-05)$ & $(3.25 \mathrm{e}-05)$ & $(3.24 \mathrm{e}-05)$ \\
\hline Grants & $0.000190 * * *$ & $0.000233 * * *$ & $0.000128 * * *$ & $0.000132 * * *$ \\
\hline & $(5.55 \mathrm{e}-05)$ & $(6.56 \mathrm{e}-05)$ & $(4.47 \mathrm{e}-05)$ & $(4.47 \mathrm{e}-05)$ \\
\hline University education (3>= years) & 0.106 & 0.0713 & $0.134 * * *$ & $0.140 * * *$ \\
\hline & $(0.0960)$ & $(0.0997)$ & $(0.0447)$ & $(0.0453)$ \\
\hline Preschool children (<7 years, percent) & -0.0782 & -0.114 & $-0.289 * *$ & $-0.308 * *$ \\
\hline & $(0.214)$ & $(0.289)$ & $(0.147)$ & $(0.147)$ \\
\hline School age children ( 7 to 16 , percent) & -0.126 & -0.199 & -0.165 & -0.164 \\
\hline & $(0.225)$ & $(0.256)$ & $(0.110)$ & $(0.110)$ \\
\hline Old $(>=65$ years $)$ & -0.0751 & -0.123 & $-0.116^{*}$ & $-0.124 *$ \\
\hline & $(0.128)$ & $(0.124)$ & $(0.0668)$ & $(0.0669)$ \\
\hline Foreign citizens & $-0.104 *$ & $-0.119 * *$ & $-0.186 * * *$ & $-0.189 * * *$ \\
\hline & $(0.0551)$ & $(0.0561)$ & $(0.0305)$ & $(0.0306)$ \\
\hline On welfare & 0.0931 & 0.0773 & -0.0687 & -0.0770 \\
\hline & $(0.132)$ & $(0.129)$ & $(0.0670)$ & $(0.0670)$ \\
\hline Interactions with preschool dummy & & & & \\
\hline Employment & $-0.273 *$ & $-0.357 * *$ & $-0.223 * *$ & $-0.216^{* *}$ \\
\hline & $(0.143)$ & $(0.153)$ & $(0.106)$ & $(0.105)$ \\
\hline Business employment & 0.476 & $0.772 * *$ & $0.0861 * * *$ & $0.0896^{* * * *}$ \\
\hline & $(3.359)$ & $(3.608)$ & $(0.0260)$ & $(0.0260)$ \\
\hline Tax base & 0.0212 & $0.173^{* * *}$ & $0.118^{* * * *}$ & $0.107 * * *$ \\
\hline & $(0.0190)$ & $(0.0537)$ & $(0.0326)$ & $(0.0321)$ \\
\hline Municipal profit/loss & $-3.63 e-05$ & $-4.68 \mathrm{e}-06$ & $-2.14 \mathrm{e}-05$ & $-2.30 \mathrm{e}-05$ \\
\hline & $(4.73 \mathrm{e}-05)$ & $(4.43 \mathrm{e}-05)$ & $(5.99 \mathrm{e}-05)$ & $(5.96 e-05)$ \\
\hline Grants & $-0.000273 * * *$ & 0.000145 & $-4.87 e-05$ & $-4.26 \mathrm{e}-05$ \\
\hline & $(8.06 \mathrm{e}-05)$ & $(0.000102)$ & $(7.69 \mathrm{e}-05)$ & $(7.71 \mathrm{e}-05)$ \\
\hline University education $(3>=$ years $)$ & $0.507 * * *$ & $0.226^{*}$ & $0.246^{* * *}$ & $0.276 * * *$ \\
\hline & $(0.145)$ & $(0.133)$ & $(0.0811)$ & $(0.0818)$ \\
\hline Preschool children ( $<7$ years, percent) & $1.712 * * *$ & $1.172 * *$ & $1.276^{* * *}$ & $1.225 * * *$ \\
\hline & $(0.368)$ & $(0.502)$ & $(0.276)$ & $(0.273)$ \\
\hline School age children ( 7 to 16 , percent) & $0.490^{*}$ & -0.0704 & 0.200 & 0.160 \\
\hline & $(0.279)$ & $(0.296)$ & $(0.199)$ & $(0.196)$ \\
\hline Old $(>=65$ years $)$ & $0.550^{* * *}$ & 0.149 & $0.392 * * *$ & $0.349 * * *$ \\
\hline & $(0.209)$ & $(0.199)$ & $(0.114)$ & $(0.112)$ \\
\hline Foreign citizens & $0.148 * *$ & 0.0417 & 0.0359 & 0.0198 \\
\hline & $(0.0670)$ & $(0.0663)$ & $(0.0483)$ & $(0.0493)$ \\
\hline On welfare & 0.146 & -0.0190 & $0.253^{* *}$ & $0.215^{* *}$ \\
\hline & $(0.155)$ & $(0.145)$ & $(0.107)$ & $(0.107)$ \\
\hline Constant & -0.941 & 0.0713 & $7.511^{*}$ & $8.071^{*}$ \\
\hline & $(7.595)$ & $(7.674)$ & $(4.198)$ & $(4.203)$ \\
\hline Year fixed effects & - & Yes & Yes & Yes \\
\hline Year fixed effect $x$ preschool & - & Yes & Yes & Yes \\
\hline County fixed effects & & & Yes & Yes \\
\hline County fixed effects x preschool & & & Yes & Yes \\
\hline Observations & 5120 & 5120 & 5120 & 5120 \\
\hline Municipalities & 287 & 287 & 287 & 287 \\
\hline R-squared & 0.317 & 0.356 & 0.676 & 0.666 \\
\hline
\end{tabular}

Robust standard errors clustered on municipality in parentheses. $* * * p<0.01, * * p<0.05, * p<0.1$ 
Table A3. Outsourcing of preschools and primary schools using left preferences

Dep. var: Outsourcing (all providers, share of budget)

$(2)$

(3)

(4)

Left $x$ Pre $\left(\beta_{\mathrm{P}}\right)$

$-0.544$

$-0.663 *$

$-0.862 * * *$

$(0.333)$

(0.332)

$-1.032 * * *$

Votes $x$ Pre $\left(\gamma_{P}\right)$

$-0.0698 * * *$

$-0.107 * * *$

$-0.109 * * *$

(0.344)

Pre

(0.0193)

(0.0214)

$(0.0221)$

$-42.15 * * *$

$-37.34 * * *$

$-30.70 * * *$

$-0.105 * * *$

(7.769)

(7.530)

(8.762)

$(0.0226)$

Left

$-0.442 * *$

$-0.497 * *$

$-0.291$

$(0.220)$

(0.222)

$(0.218)$

Votes (for the left bloc)

0.00305

$-0.000708$

0.0144

(0.0120)

(0.0128)

(0.0127)

(8.732)

$-0.213$

$(0.223)$

0.0174

Votes $\mathrm{x}$ Pre $\mathrm{x}$ competitive

$0.0129)$

$-0.0307$

$(0.0493)$

Votes $\mathrm{x}$ competitive

$-0.0552 *$

(0.0291)

0.896

(2.194)

Competitive x Pre

$2.674 * *$

Competitive

(1.297)

Constant

Controls

Controls xPre

Year fixed effects

Year fixed effect $x$ Pre

County fixed effects

County fixed effects $x$ Pre

Observations

$\begin{array}{cc}0.280 & 1.263 \\ (4.546) & (4.619) \\ \text { Yes } & \text { Yes } \\ \text { Yes } & \text { Yes } \\ - & \text { Yes } \\ - & \text { Yes }\end{array}$

9.820*

9.238*

(5.468)

Yes

Yes

Yes

Yes

Yes

Yes

Yes

Yes Yes

Municipalities

$5128 \quad 5128$

Yes

Yes

287

287

5128

5128

287

Robust standard errors in parentheses. $* * * \mathrm{p}<0.01, * * \mathrm{p}<0.05, * \mathrm{p}<0.1$ 


\section{Appendix B. Description of variables}

Table B1. Description of variables.

\begin{tabular}{|c|c|}
\hline Variable name & Description \\
\hline Out & $\begin{array}{l}\text { Outsourcing of preschools or primary education as share of total costs for that service. } \\
\text { Percent. In the main specifications (Table } 3 \text { ) it refers to outsourcing to all providers. In } \\
\text { Table } 4 \text { it refers to outsourcing to private companies. }\end{array}$ \\
\hline Right & $\begin{array}{l}\text { Dummy that equals } 1 \text { if the parties in the right bloc hold a majority of the seats in the } \\
\text { municipal council. }\end{array}$ \\
\hline Votes & $\begin{array}{l}\text { Votes for the parties in the right bloc within the municipality in the county election. } \\
\text { Percent. }\end{array}$ \\
\hline Preschool & Dummy that equals 1 for preschool services and zero for primary education. \\
\hline Comp & $\begin{array}{l}\text { Competitive election. Dummy that equals } 1 \text { if the parties in the right bloc obtained } 45 \text { to } 55 \\
\text { percent of the votes in the municipal election. }\end{array}$ \\
\hline Employment & Employed as share of population. Percent \\
\hline $\begin{array}{l}\text { Business } \\
\text { employment }\end{array}$ & Private sector employment as a share of total employment. Percent \\
\hline Tax base & Taxable labor income. Unit: Kronor per capita. \\
\hline $\begin{array}{l}\text { Municipal net } \\
\text { profit/loss }\end{array}$ & Municipal net profit. Unit: Kronor per capita. \\
\hline Grants & General and cost equalizing grants from the national government. Unit: Kronor per capita. \\
\hline $\begin{array}{l}\text { University } \\
\text { education }\end{array}$ & $\begin{array}{l}\text { Share of population with a university degree equivalent to three or more years of study. } \\
\text { Percent. }\end{array}$ \\
\hline Preschool children & Share of population that is six years old or younger. Percent. \\
\hline School age children & Share of population that is between seven and sixteen years old. Percent. \\
\hline Old & Share of population that is 65 years or older. Percent. \\
\hline Foreign citizens & Share of population who are not Swedish citizens. Percent. \\
\hline On welfare & Share of population that receives public subsistence supports. Percent. \\
\hline
\end{tabular}

Sources: Statistics Sweden. 